\title{
Article
}

\section{"Take It or Leave It" - Factors Regulating Competence Development and DNA Uptake in Campylobacter jejuni}

\author{
Julia C. Golz and Kerstin Stingl * (1) \\ German Federal Institute for Risk Assessment, Department of Biological Safety, National Reference Laboratory \\ for Campylobacter, 12277 Berlin, Germany; Julia.Golz@bfr.bund.de \\ * Correspondence: Kerstin.Stingl@bfr.bund.de; Tel.: +49-30-18412-24206
}

Citation: Golz, J.C.; Stingl, K. “Take It or Leave It" - Factors Regulating Competence Development and DNA Uptake in Campylobacter jejuni. Int. J. Mol. Sci. 2021, 22, 10169. https:// doi.org/10.3390/ijms221810169

Academic Editor: Kunio Takeyasu

Received: 17 August 2021

Accepted: 15 September 2021

Published: 21 September 2021

Publisher's Note: MDPI stays neutral with regard to jurisdictional claims in published maps and institutional affiliations.

Copyright: (c) 2021 by the authors. Licensee MDPI, Basel, Switzerland. This article is an open access article distributed under the terms and conditions of the Creative Commons Attribution (CC BY) license (https:/ / creativecommons.org/licenses/by/ $4.0 /)$.

\begin{abstract}
Campylobacter jejuni has a large adaptive potential due to enormous genetic exchange Factors regulating natural transformation in this food-borne pathogen are largely unknown but of interest for the application of sustained reduction strategies in the food-processing industry. Using a single cell DNA uptake assay, we visualized that recognition of methylated C. jejuni DNA was essential for the first step of DNA uptake into a DNase resistant state. Transformation rates using a resistance marker correlated with the fraction of competent bacteria, harboring one to maximally four locations of active DNA uptake, not necessarily being located at the cell pole. Competence developed with rising $\mathrm{pH}$ between 6.5 and 7.5 under microaerobic conditions and was nearly insensitive towards growth temperatures between $32{ }^{\circ} \mathrm{C}$ and $42{ }^{\circ} \mathrm{C}, \mathrm{CO}_{2}$ concentrations ranging from 0 to $50 \%$ and growth rates. However, competence development was abolished at $\mathrm{pH} 5$ or under aerobic stress conditions, in which the bacteria ceased growth but fully survived. The DNA uptake machinery in competent bacteria shut down at slightly acidic $\mathrm{pH}$ and was reversibly switched on upon neutralization. It was dependent on the proton motive force and, in contrast to competence development, slightly enhanced under aerobic conditions. The results suggest that natural transformation in C. jejuni occurs in the neutral and microaerobic intestinal environment for enhanced genetic diversity and pre-adaption before host switch. In addition, highly competent bacteria might be shed into the environment, still able to acquire genetic material for increased survival.
\end{abstract}

Keywords: natural transformation; genetic diversity; adaptation; $\mathrm{pH}$ regulation

\section{Introduction}

Campylobacter jejuni is a human foodborne pathogen causing the majority of bacterially induced gastroenteritis in the European Union, with 220,682 reported cases in 2019 [1]. The pathogen resides in birds, but also pigs, cattle and other animals are frequently colonized by the bacterium [2-4]. C. jejuni infection of humans primarily occurs via contaminated food, in particular due to cross-contamination from raw poultry meat to ready-to-eat fresh food and by consumption of undercooked poultry, other raw meat and milk $[5,6]$.

Campylobacter is highly sensitive to environmental stress. Microaerobic conditions and temperatures between $37{ }^{\circ} \mathrm{C}$ and $42{ }^{\circ} \mathrm{C}$ are optimal growth conditions for C. jejuni, while the bacterium cannot grow below $30^{\circ} \mathrm{C}$ or under atmospheric oxygen levels $[7,8]$. However, Campylobacter exhibits enormous survival strategies and is highly adapted to surviving harsh conditions by undergoing the viable but non-culturable state [9], but also by adaptation mechanisms [10-12] and by genetic exchange [13]. Recently, we identified by whole genome sequencing with $k$-mer analysis, that some $C$. coli strains harbored $15 \%$ introgression of $C$. jejuni sequences [14]. The gene set with $C$. jejuni introgression displayed potential roles in stress defense, suggesting enormous adaptation by natural transformation.

Although natural transformation is widespread among bacteria and offers the chance to acquire new genes or gene variants, it may be harmful for genome integrity [15-17]. 
Therefore, the process is usually regulated and limited to a subset of the bacterial population. Bistability of bacteria, tightly regulated using a main competence regulator or silencing of DNA uptake genes by non-coding small RNA have been identified to integrate various internal and external stimuli for the control of competence development and DNA uptake in some example bacteria, like Bacillus subtilis, Streptococcus, Vibrio and Legionella [18-20]. However, for most other bacteria, even the parameters for stimulating or inhibiting competence development are largely unknown.

The expression of the competence genes encoding a type IV secretion system in a close relative of $C$. jejuni, Helicobacter pylori, was differently expressed in a strain-dependent manner [21]. Natural transformation in H. pylori was shown to be tightly regulated by $\mathrm{pH}$ and oxidative stress [22]. A pH above 6.5 opened up a window for transformation, in which increase in $\mathrm{pH}$ and oxygen levels drastically stimulated DNA uptake, conditions prevailing at the multiplication site of the pathogen. In Campylobacter, natural transformation was observed to be most effective in exponential growth phase and parameters were, thereafter, varied within a $4 \mathrm{~h}$ assay with contact to chromosomal DNA and selection of resistant transformants [23]. In that study alkaline $\mathrm{pH}, 42{ }^{\circ} \mathrm{C}$ and aerobic as well as microaerobic conditions led to increase in the number of transformants. In another study, a positive correlation between lower $\mathrm{CO}_{2}$ concentrations and higher transformation levels was described [24]. A growth condition, in which C. jejuni did not take up any DNA was not identified.

In contrast to H. pylori, C. jejuni also restricts DNA uptake by differentiation between own and foreign external DNA [25] by recognition of a CtsM methylated RATTY motif frequently present in C. jejuni chromosomal DNA [26]. The mechanism of DNA uptake in C. jejuni is similar to other bacteria, using a type II-secretion/type IV pilus system in combination with the ComEC master inner membrane channel, which is common to all transformable bacteria [27-30].

Here we used a single cell-based assay to directly monitor DNA uptake in the foodborne pathogen $C$. jejuni. For the first time we were able to independently test parameters for stimulating or inhibiting competence development or DNA uptake. As observed for H. pylori, competence development was dependent on neutral to slightly alkaline $\mathrm{pH}$. In contrast, aerobic conditions prevented competence development but not DNA uptake. Interestingly, $C$. jejuni grew in the absence of $\mathrm{CO}_{2}$ despite of increased generation times, with competence development being unaffected. The DNA uptake itself was energy-dependent, insensitive against oxygen but shut down at slightly acidic $\mathrm{pH}$. More close understanding of the mechanisms and the parameters influencing natural transformation in C. jejuni are useful for the development of strategies inhibiting the pathogen's adaptive potential. This may support the design of sustainably effective reduction strategies against the pathogen in food-supplying animals.

\section{Results}

2.1. DNA Uptake in C. jejuni Occurs at Distinct Locations, Is DNA Substrate Specific and Energy-Dependent

In contrast to H. pylori, C. jejuni DNA uptake is limited to DNA substrates, which harbor RATTY sites methylated by Campylobacter spp. specific CtsM methylase [26]. Thus, in order to establish the single cell assay for $C$. jejuni, genomic DNA extracted from C. jejuni served as DNA substrate, rather than DNA of the E. coli bacteriophage $\lambda$, previously used for H. pylori. As proof-of-principle, both DNA substrates were labelled with fluorescein and $C$. jejuni cells in exponential growth phase were challenged by these two sorts of covalently labeled DNA. After incubation at $37^{\circ} \mathrm{C}$ for $30 \mathrm{~min}$ and subsequent degradation of external non-incorporated DNA by $5 \mathrm{~min}$ of DNaseI digestion at $37^{\circ} \mathrm{C}$, bacteria were immobilized using an agarose gel surface and microscopically analyzed. The bacteria harboring at least one DNase-resistant fluorescent focus were considered competent for natural transformation (Figure 1). Using $\lambda$-DNA lacking methylation at the recognition motif RATTY, no DNA focus was detected in C. jejuni BfR-CA-14430 grown for $18 \pm 4 \mathrm{~h}$ in Bolton broth (final $\mathrm{pH}$ of 7.5) (Figure 1A,B). When C. jejuni genomic DNA was used 
as substrate, bacteria showed competence levels of around $45.1 \pm 5.8 \%$ (Figure 1B,C). Analyzing this competent fraction in detail, $70.8 \pm 6.5 \%$ of the competent cells harbored one DNase-resistant fluorescent focus, $24.8 \pm 4.3 \%$ showed two foci and $4.1 \pm 3.0 \%$ even displayed three visually separated locations of DNA uptake (Figure 1D). Only very few bacteria were observed with four DNA foci $(0.3 \pm 0.3 \%)$.

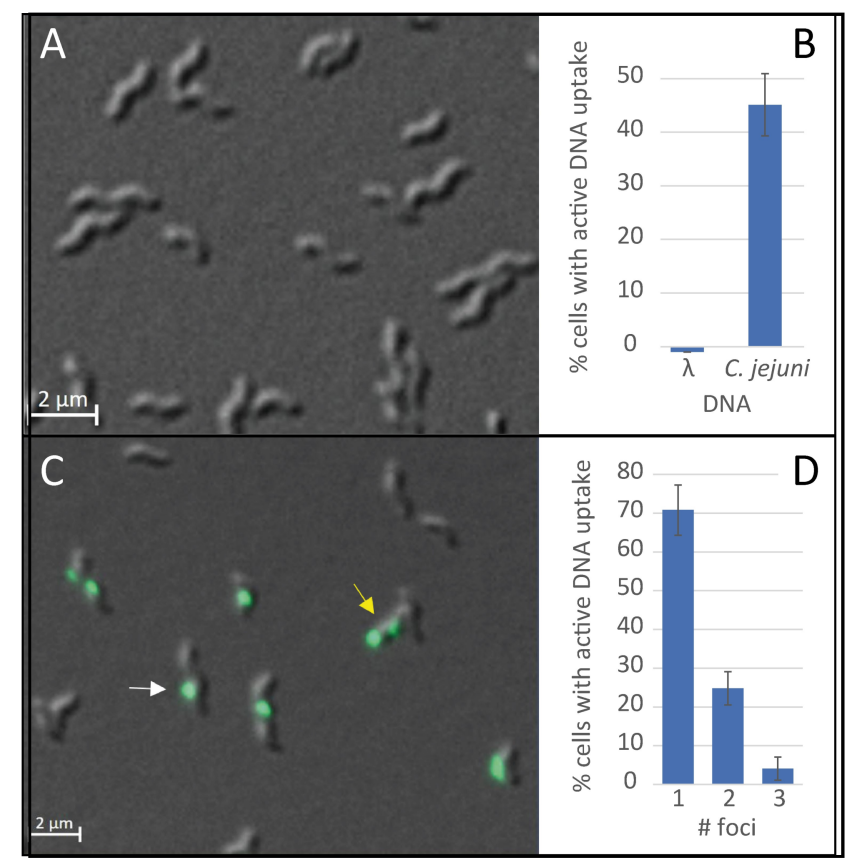

Figure 1. DNA uptake in C. jejuni BfR-CA-14430 occurs at distinct locations and is dependent on the DNA substrate. C. jejuni were incubated with fluorescently labelled DNA of the bacteriophage $\lambda$ (A) or C. jejuni DNA (C) and the fraction of cells with active DNA uptake (B) and the distribution of number of DNA foci (D) after contact to C. jejuni DNA were quantified. Arrows in (C) indicate example bacteria with one (white) and two (yellow) DNA uptake locations. Overlay image of differential phase contrast (DIC) and Fluorescein channel. Scale bar, $2 \mu \mathrm{m}$. Experiments were performed at least three times. Error bars indicate standard deviation. \#, number.

This result suggests that recognition of methylated RATTY is necessary at the very first step of DNA uptake, namely transport of DNA from the environment into a DNaseresistant state (periplasm). It also corroborates the idea that the assay was suitable for detection of DNA uptake into C. jejuni.

We further checked if the process of DNA uptake was dependent on the proton motive force (pmf), as shown for other bacteria [31,32]. For this purpose, we modulated the conditions during the time period, in which competent cells were in contact with the fluorescent genomic C. jejuni DNA. Under "standard DNA uptake conditions" using brain heart infusion (BHI), nearly half of the bacteria $(49.1 \pm 2.2 \%)$ showed active DNA uptake within $30 \mathrm{~min}$ of uptake period (Figure 2). When C. jejuni were pre-incubated for $10 \mathrm{~min}$ with $250 \mu \mathrm{M}$ of the protonophore, carbonyl cyanide m-chlorophenyl hydrazine (CCCP), which abolishes the proton gradient across the inner membrane [33], DNA uptake capacity was completely lost (Figure 2).

Furthermore, we limited the nutrient supply by incubation of competent cells for $2 \mathrm{~h}$ in phosphate-buffered saline (PBS) under microaerobic conditions. Under these conditions, the bacteria were non-motile, as also noticed in the presence of CCCP, indicating that $\mathrm{pmf}$ is limiting, which drives flagellar movement [34]. Those nutrient-depleted C. jejuni were subsequently incubated with fluorescent DNA in the presence of PBS or in re-energizing BHI. While C. jejuni were not able to take up DNA in PBS, $29.3 \pm 5.7 \%$ of the bacteria in BHI took up DNA into a DNase resistant state (Figure 2). These re-energized bacteria also regained motility under this condition. We conclude that $C$. jejuni requires the proton 
motive force for DNA uptake. It also indicated that uptake is favored under nutrientrich conditions. Consistently, DNA uptake performed under aerobic conditions led to a $1.28 \pm 0.26$-fold increased fraction of bacteria with a visible DNA focus than under microaerobic conditions $(n=20$; Figure S1).

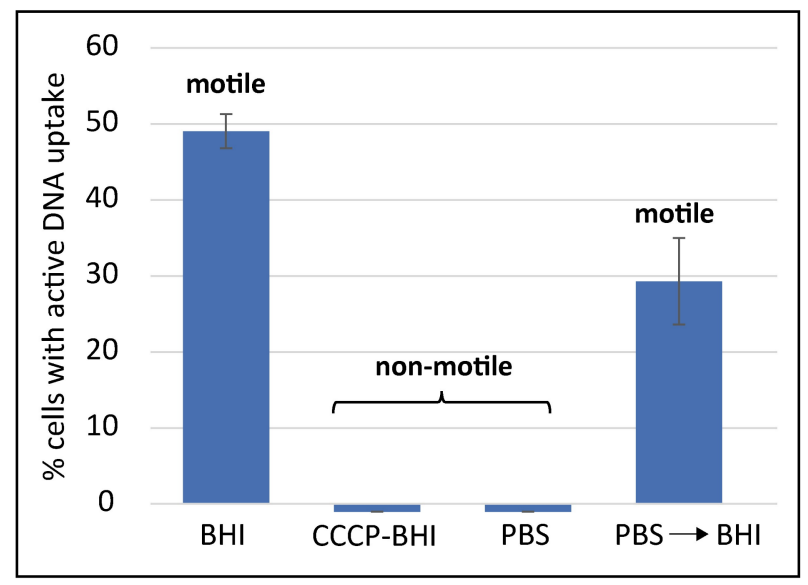

Figure 2. DNA uptake requires proton motive force. Competent $C$. jejuni pre-incubated for $10 \mathrm{~min}$ in the presence of the protonophore CCCP or nutrient-depleted for $2 \mathrm{~h}$ in PBS showed abolished DNA uptake capacity and motility. Re-energized cells (PBS $\rightarrow$ BHI; 2 h in PBS shifted to BHI during DNA uptake) regained motility and the ability to take up DNA. Experiments were performed at least three times. Error bars indicate standard deviation. PBS, phosphate-buffered saline; BHI, brain heart infusion; CCCP, carbonyl cyanide $\mathrm{m}$-chlorophenyl hydrazine.

\subsection{Competence Development in C. jejuni Is Dependent on External $\mathrm{pH}$ and Shut Down under Aerobic Conditions}

In order to decipher parameters regulating competence development in C. jejuni we used a distinct experimental setup, in which we monitored "long-term" and "short-term" effects on competence development, such as growth phase, $\mathrm{pH}$, temperature, oxidative stress and $\mathrm{CO}_{2}$ concentration (Figure 3). For fastidious bacteria, it is important to adapt optimal growth conditions in order to obtain physiological relevant data. For this purpose, C. jejuni were pre-cultured from a fresh $18 \pm 4 \mathrm{~h}$ culture on Columbia blood agar (ColBA) at an initial $\mathrm{OD}_{600 \mathrm{~nm}}$ of around 0.3 in liquid Bolton broth basis (without selective supplements) for 5 to $9 \mathrm{~h}$ to $\mathrm{OD}_{600 \mathrm{~nm}}$ of $\sim 1.5$ before sub-culturing the bacteria in the same medium. The sub-culture was modified with respect to inoculum so that $C$. jejuni reached either exponential $\left(\mathrm{OD}_{600 \mathrm{~nm}}\right.$ of 0.1 to 0.5$)$ or stationary growth phase $\left(\mathrm{OD}_{600 \mathrm{~nm}}\right.$ of 0.8 to 1.5$)$ after $18 \pm 4 \mathrm{~h}$ of incubation ("long-term" setup). Therefore, very low initial $\mathrm{OD}_{600 \mathrm{~nm}}$ between $3 \times 10^{-7}$ and $2.5 \times 10^{-5}$ for exponential or $1-5 \times 10^{-3}$ for stationary phase cultures were inoculated. In Bolton broth at $\mathrm{pH} 7.5$ growth rate of $C$. jejuni was highly reproducible with a mean generation time of $1.2 \pm 0.1 \mathrm{~h}$ (exponential phase, Table S1). To determine the effect of $\mathrm{pH}$ on competence development, $\mathrm{pH}$ of the medium was adjusted with sodium hydroxide $(\mathrm{NaOH})$ or hydrochloric acid $(\mathrm{HCl})$. 


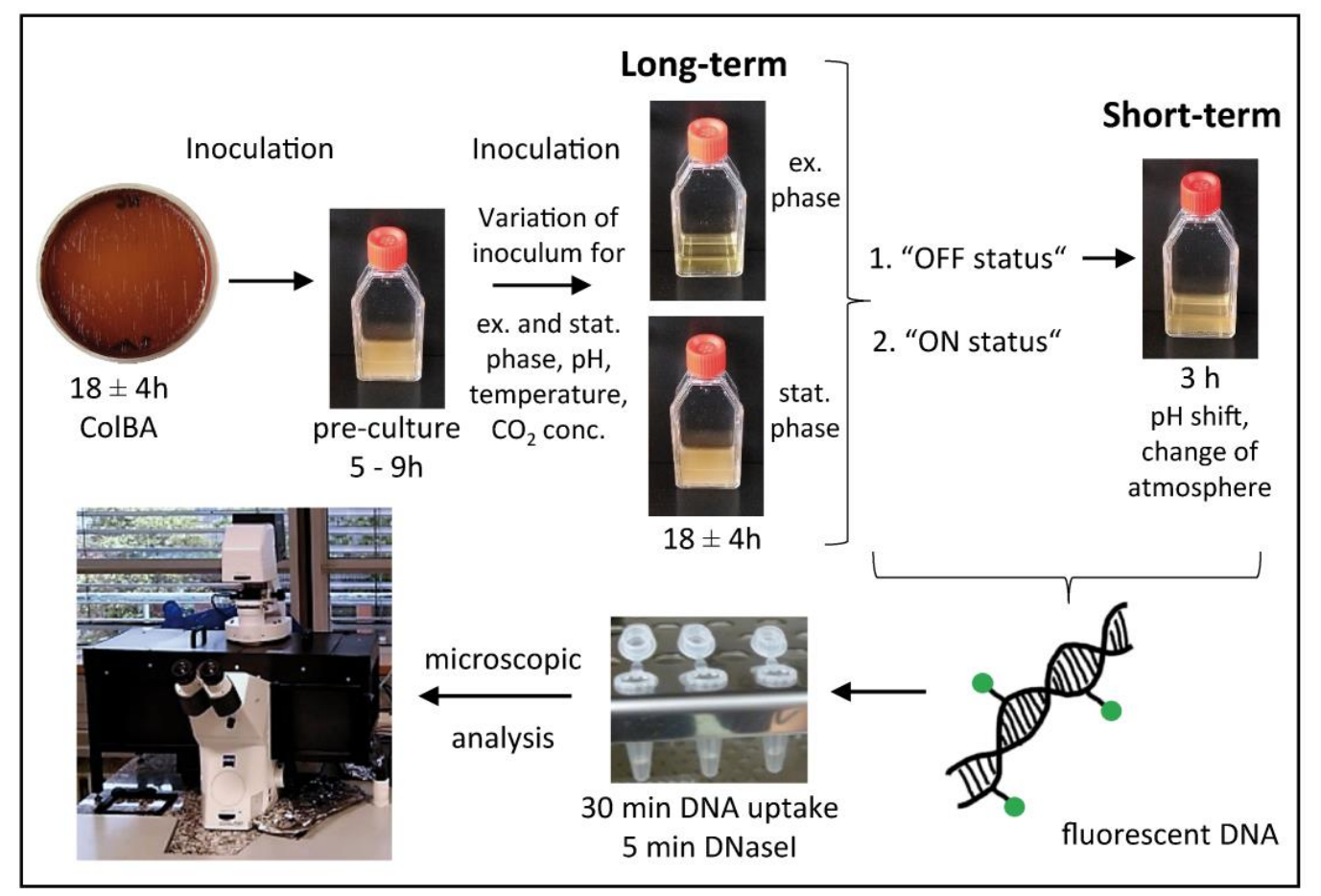

Figure 3. Schematic overview of the experimental setup of the single cell assay. All cells grown on ColBA plates were pre-cultured in Bolton broth for $5-9 \mathrm{~h}$ to stationary phase. A subculture was prepared with variation of inoculum (to reach exponential or stationary phase), $\mathrm{pH}$, temperature, $\mathrm{CO}_{2}$ concentration and incubated microaerobically for $18 \pm 4 \mathrm{~h}$. These cells were analyzed in the framework of the "long-term" setup. Cultures (from the "long-term" setup) in "OFF status" were challenged for $3 \mathrm{~h}$ by "short-term" $\mathrm{pH}$ elevation and/or atmospheric shift. After adding fluorescently labelled DNA and subsequent DNaseI digestion, bacteria were analyzed by fluorescence microscopy. Ex. phase, exponential phase culture with $\mathrm{OD}_{600 \mathrm{~nm}}$ of $0.1-0.5$; stat. phase, stationary phase culture with $\mathrm{OD}_{600 \mathrm{~nm}}$ of $0.8-1.5$; conc., concentration.

Indicated $\mathrm{pH}$ values in the text and in Figure 4 are final $\mathrm{pH}$ values after growth \pm 0.2 . The titrated $\mathrm{pH}$ at standard microaerobic conditions did not change during growth from inoculation until exponential growth phase (Figure S2, yellow squares) but was slightly increased in stationary growth phase (Figure $4, \mathrm{pH}$ values in brackets) due to $C$. jejuni metabolic activity at higher cell densities. The fraction of competent bacteria in exponential phase at $\mathrm{pH} 7.5$ was $45.1 \pm 5.8 \%$ (Figure 4 ). In stationary growth phase at a final $\mathrm{pH}$ of 7.7 this fraction of bacteria was lower comprising $27.7 \pm 5.8 \%$. When the $\mathrm{pH}$ was lowered to 6.3, a drastic decrease of the fraction of competent bacteria was observed in exponential growth phase, since only $2.3 \pm 0.9 \%$ of bacteria were observed with at least one fluorescent DNA focus (Figure 4A). A parallel culture with initial $\mathrm{pH}$ of 6.3 but grown to stationary growth phase was likewise only marginally competent with $3.5 \pm 2.1 \%$ of bacteria (Figure 4A). For all conditions depicted in Figure 4, the incubation of bacteria with fluorescent DNA was done at $\mathrm{pH}$ 7.5. An exception to this rule was the culture at $\mathrm{pH}$ 5.7, which was challenged with DNA at the same $\mathrm{pH}$ of 5.7 in order to see, if DNA uptake in C. jejuni could be completely abolished under these conditions. Indeed, not a single bacterium was observed to take up fluorescent DNA under these conditions, suggesting that slight acidic $\mathrm{pH}$ is sufficient for complete shut-down of natural transformation in $\mathrm{C}$. jejuni. However, we chose the exponential pH 6.3 and the corresponding stationary culture at 7.2 as "OFF-status" cultures for the "short-term" setup (as indicated in Figure 4A), since the generation time of $C$. jejuni at $\mathrm{pH} 5.7$ was considerably extended (Table S1). 
Table 1. Transformation rates of C. jejuni correlate with the fraction of competent cells, harboring at least one fluorescent DNA focus.

\begin{tabular}{|c|c|c|c|c|c|}
\hline Condition & $\begin{array}{c}\text { Transformation Rate } \pm \\
\text { SD }\end{array}$ & $\begin{array}{l}\text { Fraction Competent } \\
\text { Cells } \pm \text { SD }(\%)\end{array}$ & $\begin{array}{c}\text { Change in } \\
\text { Transformation Rate } \\
\text { Compared to } \mathrm{pH} 6.3\end{array}$ & $\begin{array}{l}\text { Change in Fraction of } \\
\text { Competent Cells } \\
\text { Relative to pH } 6.3\end{array}$ & $\begin{array}{c}\text { Ratio Change } \\
\text { Transformation Rate vs. } \\
\text { Change in Fraction } \\
\text { Competent Cells }\end{array}$ \\
\hline pH 5.7 & $\leq 6.9 \times 10^{-9} \pm 6.2 \times 10^{-10}$ & 0 & $\leq 0.0053$-fold & $\infty$ & n.a. \\
\hline $\mathrm{pH} 6.3$ & $1.3 \times 10^{-6} \pm 2.5 \times 10^{-6}$ & $2.3 \pm 0.9$ & 1.0-fold & 1.0-fold & 1.0 \\
\hline $\begin{array}{c}\text { pH } 6.3 \\
+3 \text { h at pH } 7.6\end{array}$ & $1.4 \times 10^{-5} \pm 7.8 \times 10^{-6}$ & $12.2 \pm 3.5$ & 10.8-fold & 5.3-fold & 2.0 \\
\hline $\begin{array}{c}\mathrm{pH} 6.3 \\
+3 \mathrm{~h} \text { with fresh medium }\end{array}$ & $2.9 \times 10^{-5} \pm 2.1 \times 10^{-5}$ & $33.9 \pm 5.0$ & 22.3-fold & 14.7-fold & 1.5 \\
\hline $\begin{array}{c}\mathrm{pH} 6.3 \\
+3 \mathrm{~h} \text { aerobic at } \mathrm{pH} 7.9\end{array}$ & $1.3 \times 10^{-6} \pm 6.4 \times 10^{-7}$ & $0.8 \pm 0.4$ & 1.0-fold & 0.3 -fold & 2.9 \\
\hline $\begin{array}{c}\mathrm{pH} 6.3 \\
+3 \mathrm{~h} \text { aerobic with fresh } \\
\text { medium }\end{array}$ & $3.7 \times 10^{-6} \pm 1.2 \times 10^{-5}$ & $3.4 \pm 1.1$ & 2.8-fold & 1.5-fold & 1.9 \\
\hline $\mathrm{pH} 7.5$ & $1.3 \times 10^{-4} \pm 2.3 \times 10^{-4}$ & $45.1 \pm 5.8$ & 100-fold & 19.6-fold & 5.1 \\
\hline pH 7.5 without DNA & $<6.4 \times 10^{-9} \pm 2.5 \times 10^{-9}$ & 0 & $<0.0049$-fold & $\infty$ & n. a. \\
\hline pH 7.3 (stat phase) & $6.6 \times 10^{-6} \pm 4.3 \times 10^{-6}$ & $3.5 \pm 2.1$ & 5.1-fold & 1.5-fold & 3.3 \\
\hline $\begin{array}{l}\text { pH } 7.3 \text { (stat phase) } \\
\text { without DNA }\end{array}$ & $<6.5 \times 10^{-9} \pm 8.0 \times 10^{-10}$ & 0 & $<0.005$-fold & $\infty$ & n.a. \\
\hline
\end{tabular}

After growth in Bolton broth at different $\mathrm{pH}$ values for $18 \pm 4 \mathrm{~h}$, bacteria were transformed with either genomic $C$. jejuni DNA carrying the streptomycin resistance marker A128G in the ribosomal rpsL gene or with fluorescent DNA in parallel. Number of transformants relative to CFU and fraction of competent cells identified by the presence of fluorescent DNaseI resistant foci were compared. Conditions are detailed in Figure 4. For estimation of spontaneous mutation rate, controls without DNA were included. Experiments were performed at least three times; $\infty$, infinite; n.a., not applicable; $<$, no transformant detected within indicated detection limit.

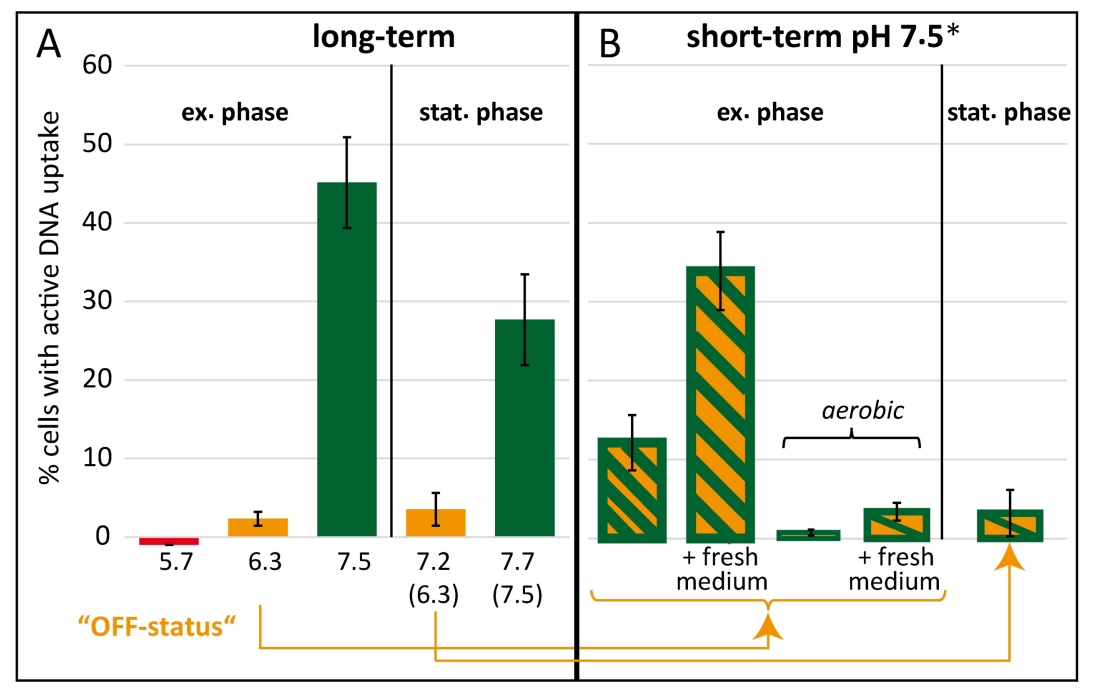

Figure 4. $\mathrm{pH}$ and atmosphere determine competence development in C. jejuni. Experimental setups for "long-term $\mathrm{pH}^{\prime}$ (A) and "short-term $\mathrm{pH}$ shift" (B) of C. jejuni BfR-CA-14430 were as described in Figure 3. Final $\mathrm{pH}$ values \pm 0.2 of cultures tested in the DNA uptake assay were as indicated, with initial $\mathrm{pH}$-values \pm 0.2 of original (exponential) cultures in brackets. The exponential culture with a final $\mathrm{pH} 6.3$ and its corresponding stationary culture without $\mathrm{pH}$ adjustment $(\mathrm{pH} 7.2)$ were used as “OFF-status" cultures for short-term $\mathrm{pH}$ shifts. Ex. phase, exponential phase culture with $\mathrm{OD}_{600 \mathrm{~nm}}$ of 0.1-0.5; stat. phase, stationary phase culture with $\mathrm{OD}_{600 \mathrm{~nm}}$ of $0.8-1.5$. Fresh medium, cultures were diluted 3 to 5-fold with Bolton broth; aerobic, atmosphere was changed to aerobic conditions for short-term challenge; *, final $\mathrm{pH} 7.9$ instead of 7.5 due to additional release of $\mathrm{CO}_{2}$ from the medium. DNA uptake occurred under aerobic conditions at $\mathrm{pH} 7.5 \pm 0.1$ except for culture $\mathrm{pH}$ 5.7, for which uptake was kept at the same $\mathrm{pH}$ value of 5.7 (see also Table 1). Experiments were performed at least three times. Error bars indicate standard deviation. 
"OFF-status" bacteria were challenged by a pH shift to 7.5 for $3 \mathrm{~h}$ in the "short-term" setup (Figure 4B). When the $\mathrm{pH}$ upshift was established by direct titration of the culture with $\mathrm{NaOH}, 12.2 \pm 3.5 \%$ of the cells took up fluorescently labelled DNA. In case we upshifted the exponential phase culture by 3- to 5-fold dilution in fresh Bolton broth at $\mathrm{pH} 7.5$ to $\mathrm{OD}_{600 \mathrm{~nm}} 0.05$, even $33.9 \pm 5.0 \%$ of the bacteria displayed active DNA uptake capacity (Figure 4B), indicating that fresh medium stimulated competence development. The stationary "OFF-status" culture did not respond during the $3 \mathrm{~h}$, indicating that those cells lost capacity to switch into the competent phase (Figure 4B).

Interestingly, when the exponential "OFF-status" culture was pH-upshifted under aerobic conditions, competence levels even decreased to $0.8 \pm 0.4 \%$ or were stable in the presence of fresh medium at low levels (Figure 4B). Since under aerobic conditions, $C$. jejuni is stressed by high oxygen levels and does not grow, survival of the bacterium under these conditions was confirmed. We observed that colony-forming units (CFU) remained constant, with $7.7 \times 10^{8} \pm 2.9 \times 10^{8} \mathrm{CFU} / \mathrm{mL}$ before and $9.3 \times 10^{8} \pm 3.2 \times 10^{8} \mathrm{CFU} / \mathrm{mL}$ after $3 \mathrm{~h}$ of aerobic incubation. Hence, the results suggested that atmospheric oxygen levels inhibited competence development even at permissive neutral to slightly alkaline $\mathrm{pH}$ values, while the bacterium arrested growth but was fully viable.

The observed increase of competence levels after exchange with fresh medium motivated us to test if several sub-cultivation steps within the exponential growth phase with fresh medium could enhance the proportion of competent cells. Therefore, we sub-cultured C. jejuni BfR-CA-14430 in Bolton broth (final pH7.5) three times with an overall growth period of more than $60 \mathrm{~h}$. We kept cells in exponential phase with maximal OD $_{600 \mathrm{~nm}}$ of 0.4 , never entering stationary phase. At each step of sub-cultivation, we determined the competence level, which was maintained at $43.4 \pm 3.4 \%$.

\subsection{Uptake of DNA into a DNase-Resistant State Is a Main Factor for Regulation of Natural Transformation}

The single cell uptake assay using covalently labelled DNA, visualizes the first step of natural transformation, i.e., DNA uptake from the environment into the cell (periplasm). In order to show its relevance for the whole process of natural transformation, we determined uptake rates and transformation rates in parallel (Table 1). Fluorescently labeled DNA and in parallel genomic C. jejuni DNA carrying the mutation A128G in rpsL conferring streptomycin resistance, were added to a C. jejuni cell suspension. As depicted in Figure 3, these cells had been grown for $18 \pm 4 \mathrm{~h}$ in liquid culture under several different conditions including growth to exponential vs. stationary phase, varying $\mathrm{pH}$ values and microaerobic vs. aerobic conditions (Figure 4). Transformation rates were calculated from the number of transformants on streptomycin-containing ColBA relative to the number of CFU under non-selective conditions. Under optimal conditions at $\mathrm{pH} 7.5$ a transformation rate of $1.3 \times 10^{-4} \pm 2.3 \times 10^{-4}$ was observed (Table 1 ).

Consistently, bacteria incubated at $\mathrm{pH}$ 5.7, which did not display any DNA uptake activity, occasionally showed one resistant colony, leading to a theoretical transformation rate of $\leq 6.9 \times 10^{-9} \pm 6.2 \times 10^{-10}$ (Table 1). The latter rate, however, was indistinguishable from a spontaneous mutation rate, since our detection limit was one resistant colony within $\sim 7 \times 10^{9}$ CFU (Table 1, values without DNA). At a slightly less acidic pH of 6.3 C. jejuni competent fraction of bacteria was $2.3 \pm 0.9 \%$, corresponding to an approximately 200-fold increased transformation rate of $1.3 \times 10^{-6} \pm 2.5 \times 10^{-6}$ in comparison to $\mathrm{pH}$ 5.7.

Furthermore, we correlated the changes in transformation rate relative to the fraction of bacteria with DNA foci, normalized to the "OFF-status" culture at pH 6.3. The higher the fraction of competent bacteria, displaying DNA uptake, the higher was the transformation rate. The correlation was not strictly linear, but had a maximal ratio of change in transformation rate versus change in fraction of competent cells in different experimental settings of 5.1-fold (Table 1). This suggested that the DNA uptake assay is a reliable tool to monitor natural transformation. 


\subsection{The Concentration of $\mathrm{CO}_{2}$ or Carbonate and Temperature Do Not Play a Pivotal Role in Competence Regulation}

During exponential growth phase, an increase in $\mathrm{pH}$ between $\mathrm{pH} 5.7$ and $\mathrm{pH} 7.5$ resulted in enhanced levels of bacteria that displayed competence (Figure 4). Under microaerobic conditions, it is expected that a more alkaline $\mathrm{pH}$ results in higher levels of dissolved $\mathrm{CO}_{2}$ and, thus, enhanced concentration of carbonate. We asked whether the amount of dissolved $\mathrm{CO}_{2}$ and the concentration of carbonate also triggered competence development in C. jejuni. Therefore, we used different $\mathrm{CO}_{2}$ concentrations in the gas atmosphere during growth at different $\mathrm{pH}$ values, keeping levels of $\mathrm{H}_{2}$ and $\mathrm{O}_{2}$ constant (Figure S3). $\mathrm{CO}_{2}$ concentrations varied between $0 \%$ and $50 \%$, with intermediate concentrations of $1 \%, 7 \%, 15 \%$ and $35 \%$. Doubling times during C. jejuni growth were optimal with around $1.1 \mathrm{~h}$ in the presence of $1 \%$ to $15 \% \mathrm{CO}_{2}$ (Table S1), suggesting that the latter concentration range perfectly supports growth of $C$. jejuni in liquid broth culture. At higher concentrations of $35 \%$ and $50 \% \mathrm{CO}_{2}$, mean generation times were marginally increased to 1.5 and $1.6 \mathrm{~h}$, respectively (Table S1). Interestingly, even without gaseous $\mathrm{CO}_{2} \mathrm{C}$. jejuni was able to grow, although with 3-fold increased mean generation times (3.4 h, Table S1). For better comparison, the fraction of competent bacteria grown under standard condition at $7 \% \mathrm{CO}_{2}$ and $\mathrm{pH} 7.5$ was set to $100 \%$ for the experimental day. Although, the day-to-day variation at low concentrations of $\mathrm{CO}_{2}(0 \%$ and $1 \%)$ seemed to be large, the $\mathrm{CO}_{2}$ concentration itself did not correlate with the kinetics of $\mathrm{pH}$-dependent switch of bacteria into the competent state (Figure S3). We also cross-checked the influence of carbonate levels on competence development in a control experiment by addition of 12 or $48 \mathrm{mM}$ of sodium hydrogen carbonate to the medium and could confirm that $\mathrm{pH}$-dependent switch into competent state was unaffected by the concentration of carbonate (Figure S4).

Furthermore, we investigated whether temperature played a role in competence development of $C$. jejuni, as indicated by others [23]. We checked the impact of growth temperature at $\mathrm{pH} 7.5$ on competence development in C. jejuni, choosing $32^{\circ} \mathrm{C}$ as minimal growth temperature and $37^{\circ} \mathrm{C}$ and $42{ }^{\circ} \mathrm{C}$ as typical host temperatures (Figure 5). The generation time of $C$. jejuni at the different temperatures was $1.2 \pm 0.1 \mathrm{~h}\left(37^{\circ} \mathrm{C}\right), 0.9 \pm 0.2 \mathrm{~h}$ $\left(42{ }^{\circ} \mathrm{C}\right)$ and $3.1 \pm 0.3 \mathrm{~h}\left(32{ }^{\circ} \mathrm{C}\right)$. We observed that competence development was optimal at $37^{\circ} \mathrm{C}$ with $45.1 \pm 5.8 \%$ (Figure $5 \mathrm{~A}$ ).

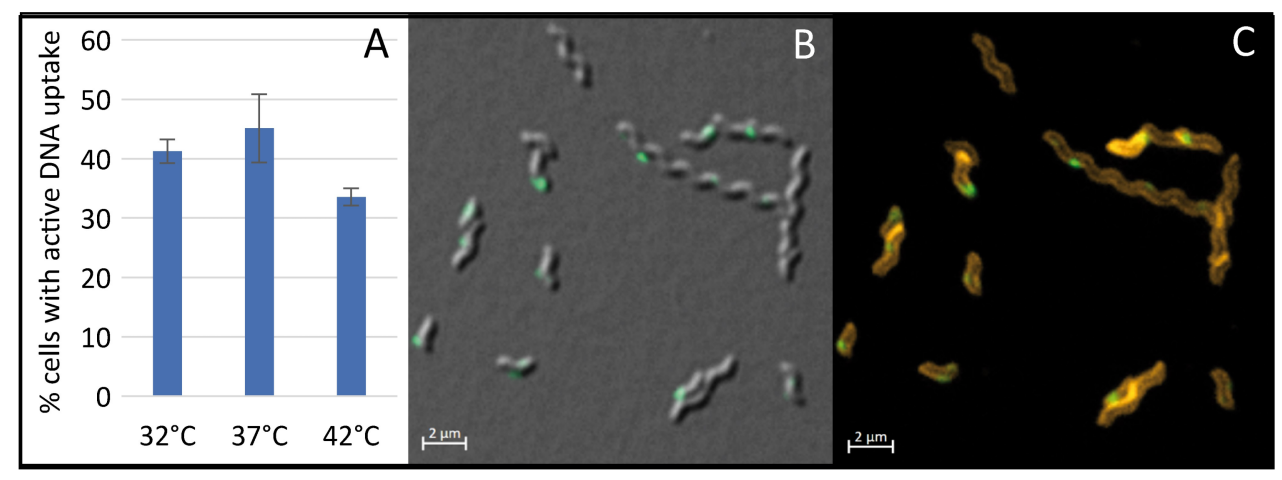

Figure 5. Growth temperature only marginally influences competence development in C. jejuni. Fraction of competent $C$. jejuni grown to exponential phase at $\mathrm{pH} 7.5$ at $32{ }^{\circ} \mathrm{C}, 37{ }^{\circ} \mathrm{C}$ and $42{ }^{\circ} \mathrm{C}$ (A). Bacterial morphology and DNA uptake locations of bacteria grown at $32^{\circ} \mathrm{C}$ were displayed by an overlay differential phase contrast (DIC) image with the Fluorescein channel (labelled DNA, in green) (B) or by an overlay image of the Fluorescein channel (labelled DNA) and the Cyanine-3 (Cy3) channel (membranes stained with the commercial dye, SynaptoRed C2) (C). Scale bar, $2 \mu \mathrm{m}$. DNA uptake was performed at $37^{\circ} \mathrm{C}$ under aerobic conditions. Experiments were performed at least three times. Error bars indicate standard deviation.

An increase in growth temperature to $42{ }^{\circ} \mathrm{C}$ resulted in a slight reduction of competence levels to $33.6 \pm 1.4 \%$. As expected for non-optimal growth temperature of 
$32{ }^{\circ} \mathrm{C}$, the culture harbored normal length bacteria but also several elongated phenotypes (Figure $5 \mathrm{~B}, \mathrm{C})$. However, competence levels were only marginally altered $(41.3 \pm 2.0 \%)$, if elongated cells were counted as one bacterium. Since in other bacteria, DNA uptake was localized at the cell poles or at the newly synthetized septum, we wondered, if this was also true for $C$. jejuni. We used the SynaptoRed $C 2$ for in vivo staining of $C$. jejuni membranes in order to detect putative septa in elongated cells (Figure 5C). However, it appeared that the elongated cells did not yet harbor a septum and that localization of DNA uptake did not necessarily occur directly at the cell pole or at the next division site.

\subsection{DNA Uptake Machinery of Competent Cells Was Shut Down at Slightly Acidic pH}

In order to evaluate the direct effect of $\mathrm{pH}$ on the DNA uptake process in already competent bacteria, multiple aliquots of a competent $C$. jejuni culture grown in BHI at $\mathrm{pH} 7.2$ and displaying a competent cell fraction of $23.7 \pm 6.2 \%$ and a transformation rate of $1.3 \times 10^{-5} \pm 8.0 \times 10^{-7}$ in BHI at $\mathrm{pH} 7.2$ were centrifuged. Subsequently, the bacteria were resuspended in $\mathrm{pH}$-adjusted medium and incubated with fluorescently labelled DNA. DNA uptake was performed for $30 \mathrm{~min}$ at microaerobic conditions and the fraction of competent cells observed in non-titrated BHI at pH 7.2 set to $100 \%$ per experimental day. Not only competence development (see above) but also the DNA uptake process was highly $\mathrm{pH}$-sensitive, with optimal transport at $\mathrm{pH}$ values between 7.2 and 8 (Figure 6).

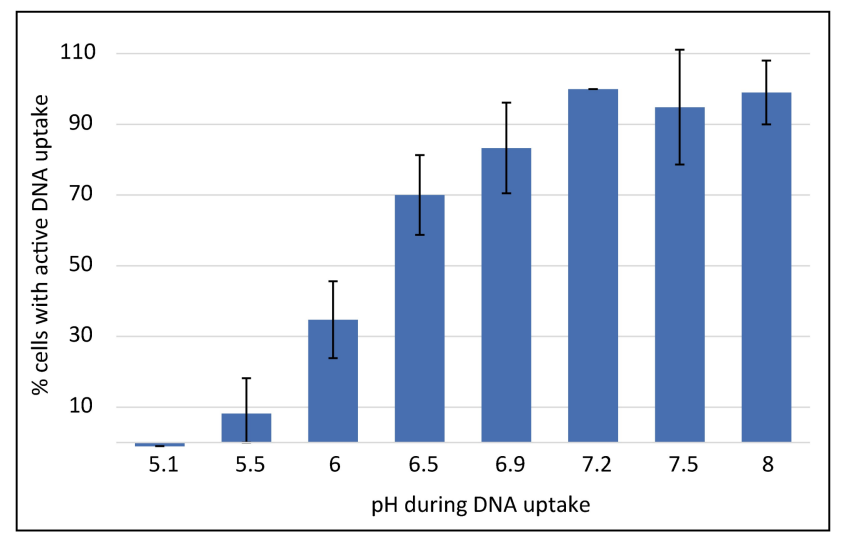

Figure 6. DNA uptake is completely shut down at slightly acidic pH. Competent C. jejuni BfRCA-14430 bacteria were incubated with fluorescently labelled DNA in BHI titrated to the indicated $\mathrm{pH}$ values $( \pm 0.1)$ under microaerobic conditions. The fraction of bacteria showing active DNA uptake are depicted, normalized to untitrated BHI, pH 7.2 condition (set to 100\%). Experiments were performed at least three times with independent cultures. Error bars indicate standard deviation. BHI, brain-heart infusion.

Between $\mathrm{pH} 7.2$ and $\mathrm{pH} 5.5$ the fraction of cells with active DNA uptake decreased to less than $10 \%$ and at $\mathrm{pH} 5.1$ DNA uptake was abolished. Likewise, transformation activity at $\mathrm{pH} 5.1$ was also drastically reduced to levels reaching the detection limit $\left(2.2 \times 10^{-9} \pm 3.8 \times 10^{-9}\right)$. By pre-incubation of the bacteria with fluorescent DNA at $\mathrm{pH} 5.1$ for $30 \mathrm{~min}$ and subsequent titration to $\mathrm{pH} 7.5$, we showed that genomic DNA was stable at $\mathrm{pH} 5.1$ and the $\mathrm{pH}$-dependent shut down of the DNA uptake process was reversible. These cells regained DNA uptake capacity of $59.8 \pm 3.2 \%$.

\section{Discussion}

We used a single cell DNA uptake assay to monitor DNA uptake during natural transformation in C. jejuni. As known for H. pylori, this assay visualizes uptake of fluorescently labelled DNA into a DNase-resistant state, namely the periplasm [22,32], which is the first step of natural transformation. In C. jejuni the fraction of cells with active DNA uptake correlated with transformation rates (Table 1), was energy-dependent and limited to uptake of genomic DNA of C. jejuni with the methylated RATTY motif [26], suggesting 
that the assay was an excellent tool to decipher parameters for regulation of competence development and of the DNA uptake process itself.

C. jejuni grows at temperatures above $30^{\circ} \mathrm{C}$ [35]. In cattle, pigs and other warmblooded animals, including the human being, the typical temperature is around $37^{\circ} \mathrm{C}$, while in birds $C$. jejuni thrives at an elevated temperature of $42^{\circ} \mathrm{C}$. C. jejuni is a fastidious bacterium with special needs for growth and survival [36]. $\mathrm{pH}$ was revealed as major regulating parameter for competence development and DNA uptake itself. Using the classical approach with a chloramphenicol resistance marker, it was previously reported that natural transformation of $C$. jejuni efficiently occurred above $\mathrm{pH} 7$ [23]. Wilson and colleagues described an effect of $\mathrm{CO}_{2}$ on transformation rates [24]. Using different carbonate concentrations or $\mathrm{CO}_{2}$ levels, with highly controlled $\mathrm{pH}$ values we could reveal that $\mathrm{CO}_{2}$ or carbonate levels did not affect competence in $C$. jejuni but that $\mathrm{pH} \geq 7$ was a prerequisite for efficient natural transformation activity. At $\mathrm{pH} 5$ competence development and DNA uptake activity in C. jejuni was completely shut down.

Under non-growing conditions, i.e., at atmospheric conditions, $C$. jejuni ceased competence development even at permissive $\mathrm{pH}$ without losing viability. This is in contrast to H. pylori where oxidative stress was a stimulating factor for competence development [22]. However, when we measured the regulation of functional DNA uptake complexes, competent bacteria even showed slightly enhanced DNA uptake under aerobic conditions (Figure S1). In C. coli natural transformation of point mutation resistances was also not reduced in an aerobic atmosphere, after the cells had been grown to exponential phase under microaerobic conditions [37]. Now that our study enabled us to dissect competence development and the DNA uptake process in C. jejuni, the data suggest that outside the host Campylobacter would not be able to develop competence. However, if competent cells are shedded from the host, these bacteria might still be able to undergo genetic exchange.

At $\mathrm{pH}$ 7.5, and under microaerobic conditions a transformation rate of $1.3 \times 10^{-4} \pm 2.3 \times 10^{-4}$ and around $50 \%$ cells with active DNA uptake were observed. Hence, one out of 4000 cells with active DNA uptake successfully recombined the genomic rpsL resistance marker into the chromosome and was able to grow on streptomycincontaining agar plates. Several steps of sub-cultivation in fresh medium did not further enhance competence development, confirming that bacteria stay bimodal and do not switch completely into the competent state. Variation of $\mathrm{pH}$ and incubation at aerobic atmosphere drastically influenced both the fraction of competent $C$. jejuni and the number of transformants. This demonstrated that the single cell assay was a suitable tool for direct monitoring of natural transformation capacity. It also implicated that regulation of natural transformation in C. jejuni primarily occurred at the level of regulation of the first step of DNA uptake, as observed for $H$. pylori $[21,22]$. Consecutive steps of natural transformation, like DNA uptake into the cytoplasm or homologous recombination appeared to be quite stable under our tested conditions, however, limiting resistance marker expression.

Growth but not cell division seemed to be important for competence development (Figures 4 and 5). In stationary growth phase, DNA uptake capacity was slightly reduced. Absence of $\mathrm{CO}_{2}$ did support growth of $C$. jejuni under our conditions. The inoculum of $3 \times 10^{-7}$ and $2.5 \times 10^{-5}$, corresponding to only 1500 to $1.25 \times 10^{5}$ bacteria per $\mathrm{mL}$ (assuming that $\mathrm{OD}_{600}$ of 0.2 corresponds to $10^{9}$ cell counts per $\mathrm{ml}$ [38]) guaranteed that respiration of $C$. jejuni was insufficient to significantly elevate the $\mathrm{CO}_{2}$ concentration in the medium. Growth at zero $\mathrm{CO}_{2}$ or at limiting growth temperature of $32{ }^{\circ} \mathrm{C}$ led to prolonged generation times and potential elongated cell morphology, but did not drastically affect competence development. Hence, neither the frequency of cell division nor the length of the generation time seemed to be signals for competence development. This was consistent with the finding that localization of DNA uptake in C. jejuni, as observed in H. pylori [22], did not strictly occur at the cell poles, as was previously shown for B. subtilis [39,40].

For colonization of the avian gut, $C$. jejuni has to first passage through the esophagus into the crop. The $\mathrm{pH}$ in the crop is largely influenced by the ingested food. It has been mostly measured to range between 4 and 6, with maximal values reported below 7 [41]. The 
$\mathrm{pH}$ decreases to around 3 to 4 in the gizzard due to gastric juice secretion. Our data suggest that $C$. jejuni is non-competent within passage through these parts of the avian digestive system. Once reaching the intestine, $\mathrm{pH}$ rises to 6-7.5, with maximal $\mathrm{pH}$ values of 7.9 [41] and competence might rapidly develop. Thus, the intestine is suggested to be the location with extensive genetic exchange between different Campylobacter spp. strains harboring DNA with the methylated DNA uptake motif. Shed competent C. jejuni are still able to take up DNA but will lose competence with time outside the host due to the inhibitory effect of atmospheric oxygen. We propose that C. jejuni increases genetic diversity at its multiplication site in order to pre-adapt to unfavorable conditions outside the host and/or for efficient host switch.

\section{Materials and Methods}

\subsection{Strains and Growth Conditions}

C. jejuni field strain BfR-CA-14430, isolated from chicken and previously sequenced [42] and reference strain $C$. jejuni $81-176$ were used. Strains were stored at $-80^{\circ} \mathrm{C}$ in cryocultures (MAST Group Ltd., Bootle, UK). Cells were cultured either on Columbia blood agar plates (ColBA, Oxoid, Thermo Fisher Scientific Inc., Waltham, MA, USA), supplemented with 5\% defibrinated sheep blood (Oxoid, Thermo Fisher Scientific Inc, Waltham, MA, USA), in brain heart infusion (BHI, Oxoid, Thermo Fisher Scientific Inc, Waltham, MA, USA) or in Bolton broth basis without selective supplements (Oxoid, Thermo Fisher Scientific, Waltham, MA, USA). The cultivation on ColBA was performed at $37^{\circ} \mathrm{C}$ under microaerobic conditions $\left(5 \% \mathrm{O}_{2}, 10 \% \mathrm{CO}_{2}\right.$, rest $\left.\mathrm{N}_{2}\right)$ using a microaerobic incubator (Binder, Tuttlingen, Germany). For the transformation experiments, selection of transformants was performed on ColBA supplemented with $20 \mu \mathrm{g} / \mathrm{mL}$ of streptomycin (Sigma-Aldrich, Steinheim, Germany).

Liquid cultures were incubated in gas replacement jars (Oxoid Anaerobia System, Thermo Fisher Scientific Inc., Waltham, MA, USA), filled with the appropriate gas mixtures (Air Liquide, Paris, France) under shaking at $140 \mathrm{rpm}$ at $37^{\circ} \mathrm{C}$. All the gas mixtures had $3.5 \% \mathrm{H}_{2}$ and $6 \% \mathrm{O}_{2}$ and only differed in the concentration of $\mathrm{CO}_{2}$ (and respective $\mathrm{N}_{2}$ ). Four gas cylinders were used: $0 \% \mathrm{CO}_{2}, 1 \% \mathrm{CO}_{2}, 7 \% \mathrm{CO}_{2}$ and $50 \% \mathrm{CO}_{2}$. Jars were evacuated to $-70 \mathrm{kPa}$ using a vacuum pump (KNF Neuberger GmbH, Freiburg im Breisgau, Germany) and the appropriate gas was filled into the jar. Evacuation to $-70 \mathrm{kPa}$ and refilling led to $70 \%$ exchange of atmosphere. The refilling process was done twice. To achieve $15 \% \mathrm{CO}_{2}$, the jar was first filled with the gas mixture containing $50 \% \mathrm{CO}_{2}$ and subsequently with $7 \%$ $\mathrm{CO}_{2}$ (1st filling: $0.7 \times 50 \% \mathrm{CO}_{2}=35 \% \mathrm{CO}_{2}$; 2 nd filling: $0.7 \times 7 \% \mathrm{CO}_{2}+0.3 \times 35 \% \mathrm{CO}_{2}$ $=15.4 \%$ ). For $35 \% \mathrm{CO}_{2}$, the jar was filled with $0 \% \mathrm{CO}_{2}$ in the first refilling process and, thereafter, with $50 \% \mathrm{CO}_{2}$ (1st filling: only $\mathrm{O}_{2}$ was decreased and $\mathrm{H}_{2}$ increased; 2nd filling: $0.7 \times 50 \% \mathrm{CO}_{2}=35 \%$ ).

$\mathrm{pH}$ of media also depends on the amount of dissolved $\mathrm{CO}_{2}$ and, thus, on the amount of gaseous $\mathrm{CO}_{2}$. Hence, opening the jar will decrease $\mathrm{CO}_{2}$, thereby, increasing $\mathrm{pH}$. We checked that during the first $10 \mathrm{~min}$ after opening the jar the $\mathrm{pH}$ only marginally increased (Figure S5) and that handling of the bacterial suspensions and $\mathrm{pH}$ measurements were acceptable within this time period.

\subsection{DNA Uptake Assay}

Genomic DNA of C. jejuni was extracted using the PureLink Genomic DNA Kit (Thermo Fisher Scientific Inc, Waltham, MA, USA) according to manufacturer's instructions. Non-methylated $\lambda$-DNA (Thermo Fisher Scientific Inc., Waltham, MA, USA) and extracted genomic C. jejuni DNA were covalently labelled with fluorescein in a 1:1 (volume:weight) ratio of Label IT reagent to nucleic acid using the Mirus Label IT Fluorescein kit (Mirus Bio LLC, Madison, WI, USA).

Cells were streaked out from a $-80{ }^{\circ} \mathrm{C}$ stock culture and sub-cultured on ColBA at $37^{\circ} \mathrm{C}$ in an incubator (Binder, Tuttlingen, Germany) under microaerobic conditions $\left(5 \% \mathrm{O}_{2}\right.$, $10 \% \mathrm{CO}_{2}$, rest $\mathrm{N}_{2}$ ) for $18 \pm 4 \mathrm{~h}$. Cells from ColBA were resuspended in $\mathrm{BHI}$ or Bolton broth 
at an initial optical density at $600 \mathrm{~nm}\left(\mathrm{OD}_{600}\right)$ of 0.3 and pre-cultured for $7 \pm 2 \mathrm{~h}$ hours using gas jars. Subsequently, cells were sub-cultured in fresh BHI or Bolton if indicated $\mathrm{pH}$ was adjusted with sodium hydroxide $(\mathrm{NaOH})$ or hydrochloric acid $(\mathrm{HCl})$. An appropriate initial $\mathrm{OD}_{600}$ to obtain a maximal $\mathrm{OD}_{600}$ of 0.5 for "exponential phase" cultures and an $\mathrm{OD}_{600}$ between 1 and 1.5 for "stationary phase" cultures, after $18 \pm 4 \mathrm{~h}$ was used. Over all conditions the initial $\mathrm{OD}_{600}$ ranged between 0.007 and $1 \times 10^{-6}$. Generation times varied between $1 \mathrm{~h}$ and $5 \mathrm{~h}$. This assay setup in which cells were grown in medium with $\mathrm{pH}$ change before $18 \pm 4$ h growth period was called "long-term $\mathrm{pH}^{\prime}$. For the assay setup "short-term $\mathrm{pH}^{\prime}$ cells were grown for $18 \pm 4 \mathrm{~h}$, then the jar was opened, $\mathrm{pH}$ was measured (Mettler Toledo, Columbus, OH, USA), and adjusted by adding a suitable volume of sodium hydroxide $(\mathrm{NaOH})$ or hydrochloric acid $(\mathrm{HCl})$. For condition "fresh medium", cultures were 3 to 5-fold diluted with fresh Bolton broth in order to reach an $\mathrm{OD}_{600}$ of 0.05 . Indicated $\mathrm{pH}$ values are $\mathrm{pH} \pm 0.1$. Cells were incubated for another $3 \mathrm{~h}$ under microaerobic conditions $\left(3.5 \% \mathrm{H}_{2}, 6 \% \mathrm{O}_{2}, 7 \% \mathrm{CO}_{2}\right.$, rest $\left.\mathrm{N}_{2}\right)$ or if indicated under aerobic conditions at $37^{\circ} \mathrm{C}$ and shaking at $140 \mathrm{rpm}$. Afterwards cells were harvested by centrifugation for $5 \mathrm{~min}$ at $16,000 \times g$ and resuspended in $100 \mu \mathrm{L}$ BHI. If indicated, $\mathrm{pH}$ was changed with $\mathrm{NaOH}$ or $\mathrm{HCl}$. For deviation of $\mathrm{pH}$ between aerobic and microaerobic conditions before and after growth see Figure S2.

For the DNA uptake assay, $1 \mu \mathrm{L}$ labelled gDNA of $C$. jejuni $(100 \mathrm{ng} / \mu \mathrm{L})$ and as a control the same amount of labelled $\lambda$-DNA (Thermo Fisher Scientific Inc., Waltham, MA, USA) were added to the cells. Incubation was performed for $30 \mathrm{~min}$ at $37^{\circ} \mathrm{C}$ under microaerobic (Figures 6, S3 and S4) or aerobic conditions (Figures 1, 2, 4 and 5). The cell suspension was centrifuged for $5 \mathrm{~min}$ at $16,000 \times g$, resuspended in $15 \mu \mathrm{L} \mathrm{BHI}$ (or Bolton broth) and incubated for $5 \mathrm{~min}$ at $37^{\circ} \mathrm{C}$ after addition of $1 \mu \mathrm{L}$ DNase (10 U) (Roche, Rotkreuz, Schweiz). If appropriate cells were stained by adding $0.4 \mu \mathrm{L} 1 \mathrm{mg} / \mathrm{mL}$ SynaptoRed C2 (Sigma-Aldrich, Steinheim, Germany) to the cell suspension. Cells were immobilized on $1.5 \%$ agarose surface. For evaluation of competence status cells were analyzed using the fluorescence microscope Zeiss Axio Observer Z1 with differential phase contrast (DIC), a metal halide light source (HXP120C) and a plan apochromatic $63 \times / 1.4$ objective. For detection of fluorescein-labelled DNA a filter set with excitation at $470 \pm 20 \mathrm{~nm}$ and emission at $525 \pm$ $25 \mathrm{~nm}$ and for detection of SynaptoRed staining a filter set with excitation at $550 \pm 12 \mathrm{~nm}$ and emission at $605 \pm 35 \mathrm{~nm}$ was used. Images were taken with a 12-bit monochromatic AxioCam MRm camera. Cells harboring at least one fluorescent focus were considered competent. For each condition at least 750 cells were counted.

To analyze if DNA uptake requires proton motive force, C. jejuni BfR-CA-14430 was preincubated for $10 \mathrm{~min}$ with $250 \mu \mathrm{M}$ CCCP before DNA uptake was performed by incubation for $30 \mathrm{~min}$ at $37^{\circ} \mathrm{C}$.

\subsection{Transformation Assay}

Cells were grown as described for the DNA uptake assay. Cells were incubated for $1 \mathrm{~h}$ under microaerobic conditions $\left(5 \% \mathrm{O}_{2}, 10 \% \mathrm{CO}_{2}\right.$, rest $\left.\mathrm{N}_{2}\right)$ at $37^{\circ} \mathrm{C}$ with $100 \mathrm{ng}$ of $\mathrm{C}$. jejuni gDNA of strain BfR-CA-14430-strep containing the point mutation A128G in rpsL, conferring streptomycin resistance. Then, cells were centrifuged for 5 min at $16,000 \times g$ and $1 \mu \mathrm{L}$ DNase [10 U/ $/ \mu \mathrm{L}]$ was added. For chromosomal integration and expression of the streptomycin resistance marker, the suspension was incubated for another $3 \mathrm{~h}$ under microaerobic conditions $\left(5 \% \mathrm{O}_{2}, 10 \% \mathrm{CO}_{2}\right.$, rest $\left.\mathrm{N}_{2}\right)$ at $37^{\circ} \mathrm{C}$ and a serial dilution of the cells was plated onto ColBA for CFU determination as well as on ColBA containing $20 \mu \mathrm{g} / \mathrm{mL}$ streptomycin for quantification of transformants. Agar plates were incubated for 2 days under microaerobic atmosphere $\left(5 \% \mathrm{O}_{2}, 10 \% \mathrm{CO}_{2}\right.$, rest $\left.\mathrm{N}_{2}\right)$ at $37^{\circ} \mathrm{C}$. Transformation rate was calculated as the ratio of transformants per $\mathrm{CFU}$.

\section{Conclusions}

The single cell assay enabled us to dissect competence development and DNA uptake in C. jejuni. Natural transformation in C. jejuni was strongly regulated by $\mathrm{pH}$ and oxidative 
stress was an inhibitory factor for competence development but not DNA uptake itself. At slightly acidic conditions, natural transformation activity was shut down. The data suggest that $C$. jejuni most probably increases genetic diversity at its multiplication site in the host intestine in order to prepare the pathogen for survival in the environment and for host switch.

Supplementary Materials: The following are available online at https://www.mdpi.com/article/10 $.3390 /$ ijms221810169/s1, Figure S1: DNA uptake is favored under aerobic compared to microaerobic conditions, Figure S2: pH variation of $\mathrm{pH}$-adjusted growth medium before and after $\mathrm{C}$. jejuni growth into exponential phase, Figure S3: pH-dependent competence development in C. jejuni BfR-CA-14430 is independent of $\mathrm{CO}_{2}$ concentration, Figure S4: Competence development depends on pH but not on sodium hydrogen carbonate, Figure S5: $\mathrm{pH}$ change of Bolton broth as a function of time after opening the jar, Table S1: Generation time and final $\mathrm{pH}$ of BfR-CA-14430 grown under different conditions.

Author Contributions: Conceptualization, K.S. and J.C.G.; methodology and investigation, J.C.G.; formal analysis, J.C.G. and K.S.; writing, J.C.G. and K.S. All authors have read and agreed to the published version of the manuscript.

Funding: This research was funded by the German Federal Ministry of Education and Research (BMBF), zoonoses research consortium PAC-CAMPY, project IP3/01KI1725B/01KI2007B.

Data Availability Statement: Data is available in the manuscript and in the Supplementary Materials.

Acknowledgments: We thank our colleagues at the NRL for Campylobacter for sustained support.

Conflicts of Interest: The authors declare no conflict of interest.

\section{References}

1. EFSA. The European Union One Health 2019 Zoonoses Report. EFSA J. 2021, 19, e06406.

2. Shange, N.; Gouws, P.; Hoffman, L.C. Campylobacter and Arcobacter species in food-producing animals: Prevalence at primary production and during slaughter. World J. Microbiol. Biotechnol. 2019, 35, 146. [CrossRef]

3. Whiley, H.; van den Akker, B.; Giglio, S.; Bentham, R. The role of environmental reservoirs in human campylobacteriosis. Int. J. Environ. Res. Public Health 2013, 10, 5886-5907. [CrossRef] [PubMed]

4. Waldenström, J.; Axelsson-Olsson, D.; Olsen, B.; Hasselquist, D.; Griekspoor, P.; Jansson, L.; Teneberg, S.; Svensson, L.; Ellström, P. Campylobacter jejuni colonization in wild birds: Results from an infection experiment. PLoS ONE 2010, 5, e9082. [CrossRef] [PubMed]

5. Rosner, B.M.; Schielke, A.; Didelot, X.; Kops, F.; Breidenbach, J.; Willrich, N.; Gölz, G.; Alter, T.; Stingl, K.; Josenhans, C.; et al. A combined case-control and molecular source attribution study of human Campylobacter infections in Germany, 2011-2014. Sci. Rep. 2017, 7, 5139. [CrossRef] [PubMed]

6. EFSA. Panel on Biological Hazards (BIOHAZ). Scientific opinion on Campylobacter in broiler meat production: Control options and performance objectives and/or targets at different stages of the food chain. EFSA J. 2011, 9, 2105. [CrossRef]

7. Doyle, M.P.; Roman, D.J. Growth and survival of Campylobacter fetus subsp. jejuni as a function of temperature and pH. J. Food Prot. 1981, 44, 596-601. [PubMed]

8. Kim, S.H.; Chelliah, R.; Ramakrishnan, S.R.; Perumal, A.S.; Bang, W.S.; Rubab, M.; Daliri, E.B.; Barathikannan, K.; Elahi, F.; Park, E.; et al. Review on stress tolerance in Campylobacter jejuni. Front. Cell. Infect. Microbiol. 2020, 10, 596570. [CrossRef] [PubMed]

9. Baffone, W.; Casaroli, A.; Citterio, B.; Pierfelici, L.; Campana, R.; Vittoria, E.; Guaglianone, E.; Donelli, G. Campylobacter jejuni loss of culturability in aqueous microcosms and ability to resuscitate in a mouse model. Int. J. Food Microbiol. 2006, $107,83-91$. [CrossRef]

10. Crofts, A.A.; Poly, F.M.; Ewing, C.P.; Kuroiwa, J.M.; Rimmer, J.E.; Harro, C.; Sack, D.; Talaat, K.R.; Porter, C.K.; Gutierrez, R.L.; et al Campylobacter jejuni transcriptional and genetic adaptation during human infection. Nat. Microbiol. 2018, 3, 494-502. [CrossRef]

11. Aksomaitiene, J.; Novoslavskij, A.; Kudirkiene, E.; Gabinaitiene, A.; Malakauskas, M. Whole genome sequence-based prediction of resistance determinants in high-level multidrug-resistant Campylobacter jejuni isolates in Lithuania. Microorganisms 2020, 9, 66. [CrossRef] [PubMed]

12. Chu, H.Y.; Sprouffske, K.; Wagner, A. Assessing the benefits of horizontal gene transfer by laboratory evolution and genome sequencing. BMC Evol. Biol. 2018, 18, 54. [CrossRef] [PubMed]

13. Samarth, D.P.; Kwon, Y.M. Horizontal genetic exchange of chromosomally encoded markers between Campylobacter jejuni cells. PLoS ONE 2020, 15, e0241058. [CrossRef] [PubMed]

14. Golz, J.C.; Epping, L.; Knüver, M.T.; Borowiak, M.; Hartkopf, F.; Deneke, C.; Malorny, B.; Semmler, T.; Stingl, K. Whole genome sequencing reveals extended natural transformation in Campylobacter impacting diagnostics and the pathogens adaptive potential. Sci. Rep. 2020, 10, 3686. [CrossRef] [PubMed] 
15. Golz, J.C.; Stingl, K. Natural competence and horizontal gene transfer in Campylobacter. Curr. Top Microbiol. Immunol. 2021, 431, 265-292. [PubMed]

16. Attaiech, L.; Boughammoura, A.; Brochier-Armanet, C.; Allatif, O.; Peillard-Fiorente, F.; Edwards, R.A.; Omar, A.R.; MacMillan, A.M.; Glover, M.; Charpentier, X. Silencing of natural transformation by an RNA chaperone and a multitarget small RNA. Proc. Natl. Acad. Sci. USA 2016, 113, 8813-8818. [CrossRef] [PubMed]

17. Engelmoer, D.J.; Donaldson, I.; Rozen, D.E. Conservative sex and the benefits of transformation in Streptococcus pneumoniae. PLoS Pathog. 2013, 9, e1003758. [CrossRef]

18. Attaiech, L.; Charpentier, X. Silently transformable: The many ways bacteria conceal their built-in capacity of genetic exchange. Curr. Genet. 2017, 63, 451-455. [CrossRef]

19. Dubnau, D.; Blokesch, M. Mechanisms of DNA uptake by naturally competent bacteria. Annu. Rev. Genet. 2019, 53, 217-237. [CrossRef]

20. Johnston, C.; Martin, B.; Fichant, G.; Polard, P.; Claverys, J.P. Bacterial transformation: Distribution, shared mechanisms and divergent control. Nat. Rev. Microbiol. 2014, 12, 181-196. [CrossRef]

21. Corbinais, C.; Mathieu, A.; Damke, P.P.; Kortulewski, T.; Busso, D.; Prado-Acosta, M.; Radicella, J.P.; Marsin, S. ComB proteins expression levels determine Helicobacter pylori competence capacity. Sci. Rep. 2017, 7, 41495. [CrossRef]

22. Krüger, N.J.; Knüver, M.T.; Zawilak-Pawlik, A.; Appel, B.; Stingl, K. Genetic diversity as consequence of a microaerobic and neutrophilic lifestyle. PLoS Pathog. 2016, 12, e1005626. [CrossRef]

23. Vegge, C.S.; Brondsted, L.; Ligowska-Marzeta, M.; Ingmer, H. Natural transformation of Campylobacter jejuni occurs beyond limits of growth. PLOS ONE 2012, 7, e45467.

24. Wilson, D.L.; Bell, J.A.; Young, V.B.; Wilder, S.R.; Mansfield, L.S.; Linz, J.E. Variation of the natural transformation frequency of Campylobacter jejuni in liquid shake culture. Microbiology 2003, 149 Pt 12, 3603-3615. [CrossRef]

25. Wang, Y.; Taylor, D.E. Natural transformation in Campylobacter species. J. Bacteriol. 1990, 172, 949-955. [CrossRef]

26. Beauchamp, J.M.; Leveque, R.M.; Dawid, S.; DiRita, V.J. Methylation-dependent DNA discrimination in natural transformation of Campylobacter jejuni. Proc. Natl. Acad. Sci. USA 2017, 114, E8053-E8061. [CrossRef]

27. Jeon, B.; Zhang, Q. Cj0011c, a periplasmic single- and double-stranded DNA-binding protein, contributes to natural transformation in Campylobacter jejuni. J. Bacteriol. 2007, 189, 7399-7407. [CrossRef] [PubMed]

28. Jeon, B.; Muraoka, W.; Sahin, O.; Zhang, Q. Role of Cj1211 in natural transformation and transfer of antibiotic resistance determinants in Campylobacter jejuni. Antimicrob. Agents Chemother. 2008, 52, 2699-2708. [CrossRef] [PubMed]

29. Wiesner, R.S.; Hendrixson, D.R.; DiRita, V.J. Natural transformation of Campylobacter jejuni requires components of a type II secretion system. J. Bacteriol. 2003, 185, 5408-5418. [CrossRef]

30. Beauchamp, J.M.; Erfurt, R.S.; DiRita, V.J. Characterization and localization of the Campylobacter jejuni transformation system proteins CtsE, CtsP, and CtsX. J. Bacteriol. 2015, 197, 636-645. [CrossRef] [PubMed]

31. Maier, B.; Chen, I.; Dubnau, D.; Sheetz, M.P. DNA transport into Bacillus subtilis requires proton motive force to generate large molecular forces. Nat. Struct. Mol. Biol. 2004, 11, 643-649. [CrossRef] [PubMed]

32. Stingl, K.; Müller, S.; Scheidgen-Kleyboldt, G.; Clausen, M.; Maier, B. Composite system mediates two-step DNA uptake into Helicobacter pylori. Proc. Natl. Acad. Sci. USA 2010, 107, 1184-1189. [CrossRef]

33. Cohen, E.J.; Nakane, D.; Kabata, Y.; Hendrixson, D.R.; Nishizaka, T.; Beeby, M. Campylobacter jejuni motility integrates specialized cell shape, flagellar filament, and motor, to coordinate action of its opposed flagella. PLoS Pathog. 2020, 16, e1008620. [CrossRef]

34. Blair, D.F. Flagellar movement driven by proton translocation. FEBS Lett. 2003, 545, 86-95. [CrossRef]

35. Hazeleger, W.C.; Wouters, J.A.; Rombouts, F.M.; Abee, T. Physiological activity of Campylobacter jejuni far below the minimal growth temperature. Appl. Environ. Microbiol. 1998, 64, 3917-3922. [CrossRef]

36. Biesta-Peters, E.G.; Jongenburger, I.; de Boer, E.; Jacobs-Reitsma, W.F. ISO_10272-1:2017, Microbiology of the food chainHorizontal method for detection and enumeration of Campylobacter spp.-Part 1: Detection method. Int. J. Food Microbiol. 2019, 288, 39-46. [CrossRef] [PubMed]

37. Kim, J.S.; Kim, J.W.; Kathariou, S. Differential effects of temperature on natural transformation to erythromycin and nalidixic acid resistance in Campylobacter coli. Appl. Environ. Microbiol. 2008, 74, 6121-6125. [CrossRef] [PubMed]

38. Krüger, N.J.; Buhler, C.; Iwobi, A.N.; Huber, I.; Ellerbroek, L.; Appel, B.; Stingl, K. “Limits of control”—crucial parameters for a reliable quantification of viable Campylobacter by real-time PCR. PLoS ONE 2014, 9, e88108.

39. Hahn, J.; Maier, B.; Haijema, B.J.; Sheetz, M.; Dubnau, D. Transformation proteins and DNA uptake localize to the cell poles in Bacillus subtilis. Cell 2005, 122, 59-71. [CrossRef]

40. Kaufenstein, M.; van der Laan, M.; Graumann, P.L. The three-layered DNA uptake machinery at the cell pole in competent Bacillus subtilis cells is a stable complex. J. Bacteriol. 2011, 193, 1633-1642. [CrossRef] [PubMed]

41. Svihus, B. Effect of digestive tract conditions, feed processing and ingredients on response to NSP enzymes. In Enzymes in farm animal nutrition, 2nd ed.; Bedford, M.R., Partridge, G.G., Eds.; CAB International: Wallingford, UK, 2011; pp. 129-159. [CrossRef]

42. Epping, L.; Golz, J.C.; Knüver, M.T.; Huber, C.; Thürmer, A.; Wieler, L.H.; Stingl, K.; Semmler, T. Comparison of different technologies for the decipherment of the whole genome sequence of Campylobacter jejuni BfR-CA-14430. Gut Pathog. 2019, 11, 59. [CrossRef] [PubMed] 